\title{
CROPPER: a metagene creator resource for cross-platform and cross-species compendium studies Jussi Paananen ${ }^{1,2}$, Markus Storvik ${ }^{3}$ and Garry Wong*1,3
}

\author{
Address: ${ }^{1}$ Department of Neurobiology, A. I. Virtanen Institute for Molecular Sciences, P.O. Box 1627, 70211 Kuopio, Finland, ${ }^{2}$ Department of \\ Computer Science, University of Kuopio, P.O. Box 1627, 70211 Kuopio, Finland and ${ }^{3}$ Department of Biochemistry, University of Kuopio, P.O. \\ Box 1627, 70211 Kuopio, Finland \\ Email: Jussi Paananen - Jussi.Paananen@uku.fi; Markus Storvik - Markus.Storvik@uku.fi; Garry Wong*-Garry.Wong@uku.fi \\ * Corresponding author
}

Published: 22 September 2006

BMC Bioinformatics 2006, 7:418 doi:10.1/86/147|-2105-7-418

This article is available from: http://www.biomedcentral.com/|47|-2/05/7/4I8

(C) 2006 Paananen et al; licensee BioMed Central Ltd.

This is an Open Access article distributed under the terms of the Creative Commons Attribution License (http://creativecommons.org/licenses/by/2.0), which permits unrestricted use, distribution, and reproduction in any medium, provided the original work is properly cited.
Received: 02 June 2006

Accepted: 22 September 2006

\begin{abstract}
Background: Current genomic research methods provide researchers with enormous amounts of data. Combining data from different high-throughput research technologies commonly available in biological databases can lead to novel findings and increase research efficiency. However, combining data from different heterogeneous sources is often a very arduous task. These sources can be different microarray technology platforms, genomic databases, or experiments performed on various species. Our aim was to develop a software program that could facilitate the combining of data from heterogeneous sources, and thus allow researchers to perform genomic crossplatform/cross-species studies and to use existing experimental data for compendium studies.
\end{abstract}

Results: We have developed a web-based software resource, called CROPPER that uses the latest genomic information concerning different data identifiers and orthologous genes from the Ensembl database. CROPPER can be used to combine genomic data from different heterogeneous sources, allowing researchers to perform cross-platform/cross-species compendium studies without the need for complex computational tools or the requirement of setting up one's own in-house database. We also present an example of a simple cross-platform/cross-species compendium study based on publicly available Parkinson's disease data derived from different sources.

Conclusion: CROPPER is a user-friendly and freely available web-based software resource that can be successfully used for cross-species/cross-platform compendium studies.

\section{Background}

Novel genomic research methods have enabled researchers to perform high-throughput experiments that results in massive amounts of experimental data. Combining data from different experiments allows researchers to validate their results and to gain a better understanding of the biological questions being studied. In cross-species studies, data derived from experiments performed on different organisms are combined to find universal themes.
In cross-platform studies, common biological questions are studied using different research platforms and technologies. The ability to combine experimental data is particularly useful when extended to combine data available on public data repositories such as sequence, expression, and literature databases.

The desire to perform large-scale studies that combine experimental results from various sources has led to com- 
pendium studies that combine cross-species/cross-platform data in order to obtain a larger perspective on biological questions. Unfortunately, for several reasons, the combining of experimental results is anything but a trivial task. These reasons can be divided into biological and technical challenges. The biological challenges include variances between species, different experimental design/conditions, and lack of knowledge of the underlying biological processes. The technical challenges are caused by differences in how experimental data is stored, presented, and managed. Because of the lack of standards, different research equipment, software, and databases identify and structure data in different and unique ways that make it a challenge to combine data obtained from these heterogeneous sources.

To address these technical challenges and to enable researchers to automate the integration of the genomic data derived from heterogeneous sources, without the need for using complex programming and scripting tools, we have developed a user-friendly web-based software resource called CROPPER. CROPPER can be used to combine datasets from different genomic research platforms such as microarrays, biological databases, and experiments performed on different species. When performing the combining process, associated data can be brought along. This facilitates the import of the resulting dataset by the user into the desired statistical/analytical program for further analysis. CROPPER uses the latest genomic information with respect to identifiers and orthologous genes retrieved from the Ensembl [1] database.

\section{Implementation}

CROPPER is developed using Perl version 5.9.1, Bioperl version 1.4 [2] and Ensembl database API written in Perl [3]. CROPPER runs on a web-server which also acts as an application server. Users can use the web-interface to input their datasets and related parameters to the application server. The Application server processes the data, and if required, queries the database server containing installation of the Ensembl-database for information about data identifiers, orthologous genes, and gene annotations. Information about how the identifiers are linked and how the orthologue predictions have been performed can be found from the Ensembl-website.

CROPPER can be used to combine genomic datasets obtained from various heterogeneous sources. As an input, CROPPER takes datasets as delimited text-files. The delimited text-files can have any kind of column structure, but should include a column with an identifier for each data row. All the external database identifiers found from the Ensembl database can be used, including identifiers for major biological databases (e.g. EMBL, GenBank and
Uniprot) and technology providers (e.g. Affymetrix and Agilent).

The user can select the structure of a result file and choose a metagene identifier to be created for each data row. A metagene identifier is a common identifier automatically created by CROPPER that groups together different identifiers originating from a single gene (these identifiers can be, for example, gene or gene product identifiers, microarray probe identifiers, or identifiers of orthologous genes or products of these genes in other species). For example a gene and a protein coded by an orthologous gene in another species will have a common metagene identifier. The concept of the metagene identifiers is shown in detail in Figure 1.

\section{Results}

CROPPER can be used to combine genomic data obtained from heterogeneous sources. Because CROPPER uses the Ensembl-database for information about data identifiers and orthologous genes, the number of different possible sources of data is enormous. These sources include major technology providers and databases, and therefore CROPPER can be used to perform cross-platform studies using data from these sources. The current Ensembl-build (build 37) contains genomic information from 19 different species (and pre-versions of six additional species) including major model organisms. This allows CROPPER to be used for cross-species studies.

Using CROPPER is a straightforward process which is divided into two parts; processing of individual dataset files and combining the processed files. When processing individual files, users can choose to annotate and re-structure their dataset, and additionally add a metagene identifier for each data row. After processing the individual files and adding metagene identifiers, the processed datasets can then be directly used for analysis in suitable $3^{\text {rd }}$ party analysis software, or alternatively combined with CROPPER using the common metagene identifiers. The combining process produces a result dataset that the users can then import to the analysis software of their choice. The flow of processing and combining datasets using CROPPER is presented in Figure 2.

\section{Performing an example compendium study}

To demonstrate how CROPPER can be used in cross-species/cross-platform compendium studies, we performed a small-scale compendium study. The datasets used were; Mouse Full Powerblot Western Array dataset used for proteomic analysis after Rasagiline treatment (downloaded from GEO, GSE1857), Affymetrix GeneChip Human Genome Focus Array dataset used for gene expression profiling of parkinsonian substantia nigra pars compacta [4], Affymetrix GeneChip C. elegans Genome Array dataset 


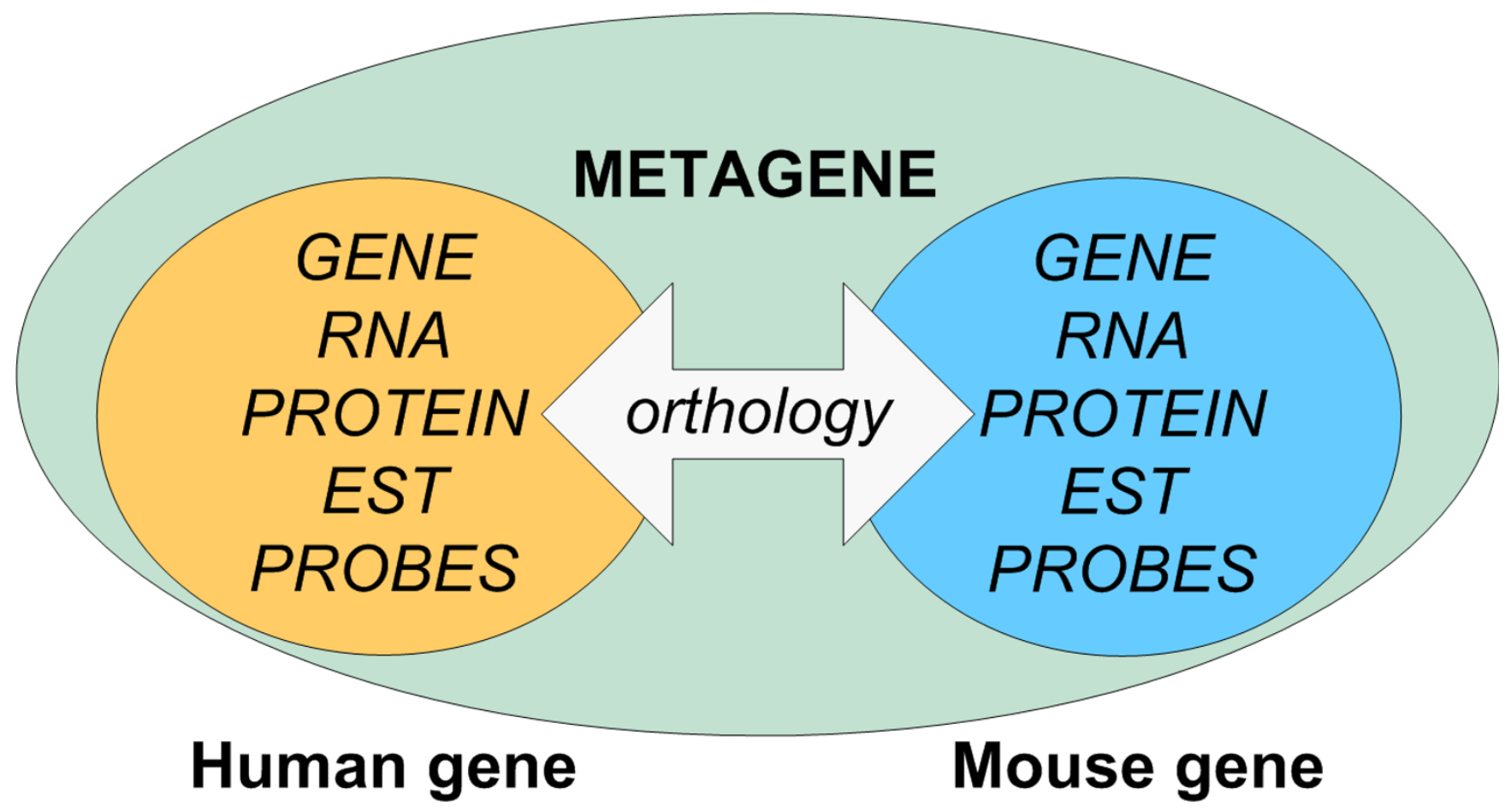

Figure I

Concept of metagenes. A metagene is a common identifier that groups together gene and gene product identifiers originating from a single gene and orthologous genes in other species. Different identifiers can be cross-linked to each other using a common metagene identifier.

used for identification of gene expression changes in transgenic C. elegans overexpressing human mutant A53T $\alpha$-synuclein [5] and Affymetrix GeneChip Human Genome 133A set used for gene expression profiling of MPTP-lesioned macaque model of Parkinson's disease [6]. The reasons for selecting these datasets were the common focus of the studies (neurodegenerative Parkinson's disease), the wide variety of covered species (Homo sapiens, Caenorhabditis elegans, Mus musculus and Macaca fascicularis) and differences in used platforms (protein and gene expression arrays). The question we wanted to study was: are there common themes between the human disease state and animal disease models? Moreover, what are the themes that can be found from genes with altered expression in animal models, but not in the humans?

CROPPER was successfully used to assign metagene identifiers to the datasets and then to combine the datasets in to a single result dataset, which was used in further analyses (see Table 1 for example of the combined result dataset). Z-transformation [7] was used to normalise the data by calculating $z$-ratios for the difference between control and treatment data in each of the original study cases (see
Additional file 1 for the complete combined result dataset with calculated z-ratios).

The genes that were present in the human dataset (4055 genes) were clustered into 16 clusters using a self-organizing map (SOM) with GeneSpring 7.2 (Agilent Technologies, USA) as presented in Figure 3. A new gene list was created from the clusters in which the expression levels greatly varied between the conditions (1262 genes). From this list, those also regulated in the human disease state (246 genes exceeding Z-ratio of \pm 1 , defined as the difference between the $z$-values of the control and treated samples divided by the standard deviation of all differences) were considered to be the most likely candidates in the disease models. The profiles of these 246 genes are marked in green in the figure 3 . In addition, the genes which were regulated in any of the animal data sets by a Z-ratio of \pm 1 , but not in the human Parkinson's disease sample (Z-ratio of >-0.2 and < 0.2) (225 genes total) are marked in red in figure 3 . These two lists of genes were inspected for the enriched KEGG-pathways by using DAVID [8] with the whole human genome as a background list and for the enriched GO-terms by using GEN- 


\section{CROPPER}
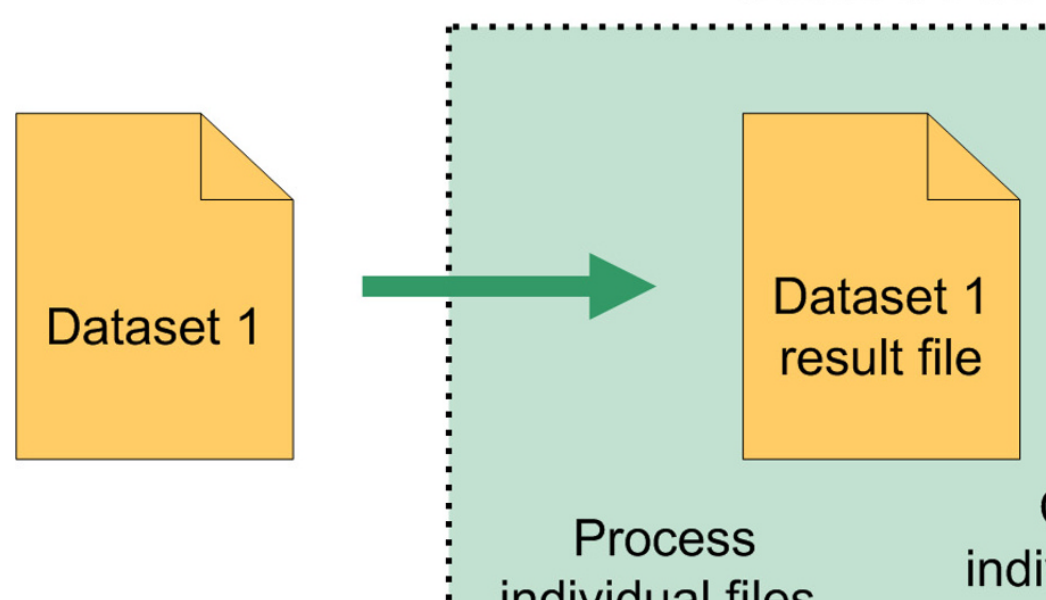

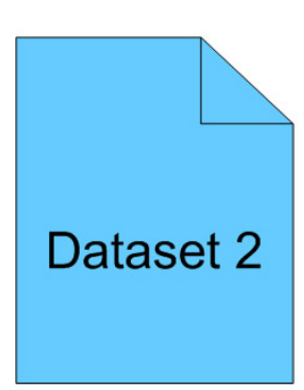

Process individual files, add metagene identifiers

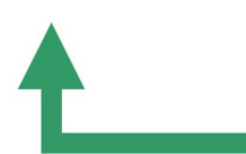

\section{Combine individual result files based on metagene identifiers}

Combined result file

\section{Repeat the process to combine with other datasets}

\section{Figure 2}

Process flow of using CROPPER. Datasets are first processed individually. This processing adds a metagene identifier to each data row. After the processing of both datasets, the datasets can be combined using the metagene identifiers. Result file containing the combined data rows is produced. Additional datasets can be combined to the result file by repeating the process and including the combined result file as the second dataset.

ERATOR [9] with the present human genes from the combined dataset as a background list. The results from different phases of the analysis are presented in the Additional file 2 .

The biological themes discovered from the lists of regulated genes suggest that biological hypotheses with explanatory power can be generated using the metagene approach. The results also suggest that combining datasets from different studies provides a valuable tool for validating results, as the human dataset was used to filter out genes not detected in the human disease state. This makes it possible to detect genes from the animal experiments that are most likely to be involved in the actual human disease, supporting a selection process of candidate genes based not only on statistical power, but also on the biological differences between species. In the analysed data, the clustering of genes based on the GO-terms revealed that the transport proteins, molecular biosynthesis mechanism, and the neurofilaments are good candidates for studies in most of the animal models for neurodegeneration. Calmodulin and calcium related modulatory mech- 


\begin{tabular}{|c|c|c|c|c|c|c|c|c|}
\hline \multirow[b]{2}{*}{ Metagene ID } & \multicolumn{2}{|r|}{ Homo sapiens } & \multicolumn{2}{|c|}{ Mus musculus } & \multicolumn{2}{|c|}{ Caenorhabditis elegans } & \multicolumn{2}{|r|}{ Macaca fascicularis } \\
\hline & $\begin{array}{l}\text { Affymetrix } \\
\text { probe ID }\end{array}$ & Gene description & Uniprot ID & $\begin{array}{c}\text { Gene } \\
\text { description }\end{array}$ & $\begin{array}{l}\text { Wormbase } \\
\text { Gene ID }\end{array}$ & Gene description & $\begin{array}{l}\text { Affymetrix } \\
\text { probe ID }\end{array}$ & Gene description \\
\hline MGD59E612 & 216248_s_at & $\begin{array}{l}\text { Orphan nuclear receptor NR4A2 } \\
\text { (Orphan nuclear receptor NURRI) } \\
\text { (Immediate-early response protein NOT) } \\
\text { (Transcriptionally-inducible nuclear } \\
\text { receptor). }\end{array}$ & $\mathrm{Q} 06219$ & $\begin{array}{l}\text { nuclear } \\
\text { receptor } \\
\text { subfamily 4, } \\
\text { group A, } \\
\text { member } 2\end{array}$ & C48D5.I & $\begin{array}{l}\text { Nuclear hormone } \\
\text { receptor family } \\
\text { member nhr-6 (Cnr8). }\end{array}$ & 216248_s_at & $\begin{array}{l}\text { Orphan nuclear receptor NR4A2 } \\
\text { (Orphan nuclear receptor NURRI) } \\
\text { (Immediate-early response protein } \\
\text { NOT) (Transcriptionally-inducible } \\
\text { nuclear receptor). }\end{array}$ \\
\hline MGDH20656 & 200746_s_at & & P0490I & & $\mathrm{FI} 3 \mathrm{D} \mid 2.7$ & $\begin{array}{l}\text { Guanine nucleotide- } \\
\text { binding protein beta } \\
\text { subunit I. }\end{array}$ & 200746_s_at & $\begin{array}{l}\text { Guanine nucleotide-binding protein } \\
\mathrm{G}(\mathrm{I}) / \mathrm{G}(\mathrm{S}) / \mathrm{G}(\mathrm{T}) \text { beta subunit I } \\
\text { (Transducin beta chain I). }\end{array}$ \\
\hline MGDH2268I & 201533_at & Beta-catenin. & Q02248 & $\begin{array}{l}\text { catenin } \\
\text { (cadherin } \\
\text { associated } \\
\text { protein), beta } \\
\text { I }\end{array}$ & $\mathrm{K} 05 \mathrm{C} 4.6$ & $\begin{array}{l}\text { HuMPback (dorsal } \\
\text { lumps) family member } \\
\text { (hmp-2) }\end{array}$ & 201533_at & Beta-catenin. \\
\hline MGDH2286I & 203333_at & $\begin{array}{l}\text { Kinesin-associated protein } 3 \text { (Smg GDS- } \\
\text { associated protein). }\end{array}$ & P70I88 & $\begin{array}{l}\text { kinesin- } \\
\text { associated } \\
\text { protein } 3\end{array}$ & F56C9.I & $\begin{array}{l}\text { Putative serine/ } \\
\text { threonine protein } \\
\text { phosphatase F56C9.I in } \\
\text { chromosome III (EC } \\
\text { 3.I.3.16). }\end{array}$ & 203333_at & $\begin{array}{l}\text { Kinesin-associated protein } 3 \text { (Smg } \\
\text { GDS-associated protein). }\end{array}$ \\
\hline MGDH22922 & 200075_s_at & $\begin{array}{l}\text { Guanylate kinase (EC 2.7.4.8) (GMP } \\
\text { kinase). }\end{array}$ & Q64520 & $\begin{array}{l}\text { guanylate } \\
\text { kinase I }\end{array}$ & T03FI.8 & & 200075_s_at & $\begin{array}{l}\text { Guanylate kinase (EC 2.7.4.8) (GMP } \\
\text { kinase). }\end{array}$ \\
\hline MGDH23987 & 217746_s_at & $\begin{array}{l}\text { Programmed cell death 6-interacting } \\
\text { protein (PDCD6-interacting protein) } \\
\text { (ALG-2-interacting protein I) (Hp95). }\end{array}$ & O88695 & & RIOEI2.I & $\begin{array}{l}\text { Apoptosis-linked gene } 2 \\
\text { interacting protein X I } \\
\text { (Protein pqn-58) } \\
\text { (Protein YNKI). }\end{array}$ & 217746_s_at & $\begin{array}{l}\text { Programmed cell death 6-interacting } \\
\text { protein (PDCD6-interacting } \\
\text { protein) (ALG-2-interacting protein } \\
\text { I) (HP95). }\end{array}$ \\
\hline MGDH2564 & 203087_s_at & $\begin{array}{l}\text { Kinesin-like protein KIF2 (Kinesin-2) } \\
\text { (HK2). }\end{array}$ & P28740 & $\begin{array}{l}\text { kinesin family } \\
\text { member } 2 A\end{array}$ & KIID9.I & $\begin{array}{l}\text { Kinesin-Like Protein } \\
\text { family member (klp-7) }\end{array}$ & 213598_at & $\begin{array}{l}\text { Kinesin-like protein KIF2 (Kinesin-2) } \\
\text { (HK2). }\end{array}$ \\
\hline MGDH259I & 209503_s_at & $\begin{array}{l}26 \mathrm{~S} \text { protease regulatory subunit } 8 \\
\text { (Proteasome subunit p45) (p45/SUG) } \\
\text { (Proteasome } 26 \mathrm{~S} \text { subunit ATPase 5) } \\
\text { (Thyroid hormone receptor-interacting } \\
\text { protein I) (TRIPI). }\end{array}$ & P47210 & & Y49EI0.I & $\begin{array}{l}\text { proteasome Regulatory } \\
\text { Particle, ATPase-like } \\
\text { family member (rpt-6) }\end{array}$ & 209503_s_at & $\begin{array}{l}26 \text { S protease regulatory subunit } 8 \\
\text { (Proteasome subunit } \mathrm{p} 45)(\mathrm{p} 45 / \\
\text { SUG) (Proteasome } 26 \mathrm{~S} \text { subunit } \\
\text { ATPase 5) (Thyroid hormone } \\
\text { receptor-interacting protein I) } \\
\text { (TRIPI). }\end{array}$ \\
\hline MGDH26335 & 201390_s_at & $\begin{array}{l}\text { Casein kinase II subunit beta (CK II beta) } \\
\text { (Phosvitin) (G5a). }\end{array}$ & PI3862 & & T0IG9.6 & $\begin{array}{l}\text { Casein kinase II beta } \\
\text { subunit (CK II beta). }\end{array}$ & 201390_s_at & $\begin{array}{l}\text { Casein kinase II subunit beta (CK II } \\
\text { beta) (Phosvitin) (G5a). }\end{array}$ \\
\hline MGDH2988 & 2076|4_s_at & Cullin-I (CUL-I) & Q9WTX6 & cullin I & D2045.6 & $\begin{array}{l}\text { Cullin-I (Abnormal cell } \\
\text { lineage } 19 \text { protein). }\end{array}$ & 207614_s_at & Cullin-I (CUL-I). \\
\hline MGDH6882 & 200864_s_at & & P244I0 & & F53GI2.I & $\begin{array}{l}\text { RAB family member } \\
(\text { rab-II.I) }\end{array}$ & 200864_s_at & $\begin{array}{l}\text { Ras-related protein Rab-I IA (Rab- } \\
\text { II) (YL8). }\end{array}$ \\
\hline MGDH8694 & 201220_x_at & & P56546 & $\begin{array}{l}\text { C-terminal } \\
\text { binding } \\
\text { protein } 2\end{array}$ & F49EI0.5 & & 210835_s_at & $\begin{array}{l}\text { C-terminal-binding protein } 2 \\
\text { (CtBP2). }\end{array}$ \\
\hline
\end{tabular}



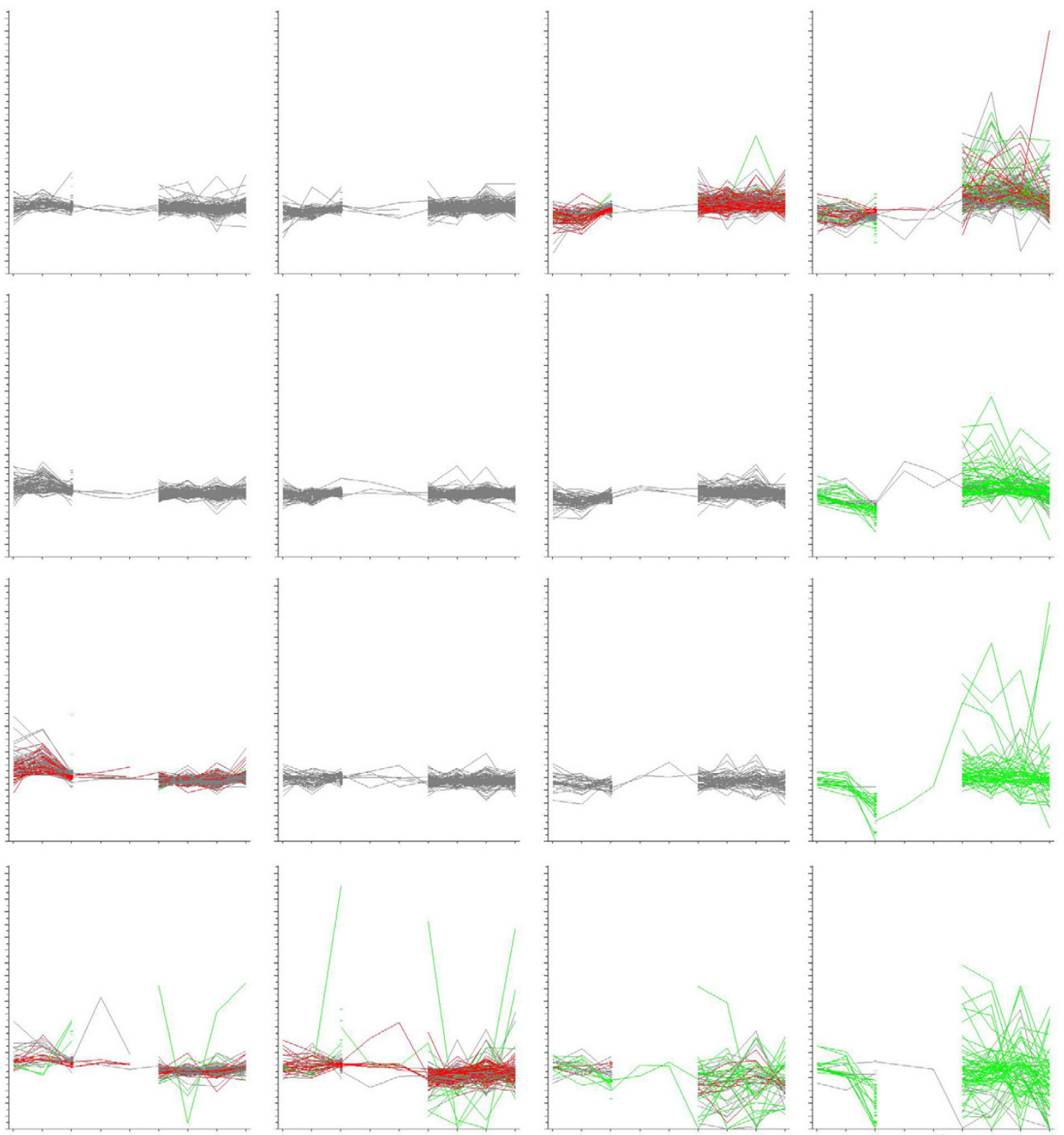

\section{Figure 3}

SOM Clustering of data combined using CROPPER. Four different Parkinson's disease datasets were combined by aligning the metagenes with CROPPER. The data consisted of a total of 9 conditions originating from the datasets. The conditions are shown in the ordinate axis and their z-transformed values are shown in the $y$-axis. For normalization, the differences in the data value distributions were z-transformed. This was followed by calculation of the z-ratio, in which the differences of the zvalues of the treated samples were subtracted from z-values of the controls (for method details, see Cheadle et al. 2002 [7]). The limit for significant alteration was z-ratio \pm I defined as more than one standard deviation in the z-values of control and treatment data points. The gene expression data from human represent 4055 metagenes. These were clustered into 16 clusters using a self-organizing map (SOM). The expression profiles of the metagenes with altered expression in both human and animal data sets were coloured in green. These 247 "green" genes were considered to be candidates for human neurodegenerative diseases. The genes with altered expression only in the animal experiment datasets, but not in the human datasets were coloured in red. The 225 "red" genes may suggest mechanisms in animal neurodegeneration models, but not in human Parkinson's disease. The separation of red and green genes to peripheral clusters indicates good clustering resolution. The lists of "red" and "green" metagenes were further analyzed for the enriched human KEGG and GO terms based on the human gene identifiers corresponding to the assigned metagenes. 
anisms are also detected in the animal models. Downstream data extraction can be performed by export of the combined data to view enriched terms from the KEGG pathway (Additional file 2), that then can be used to create new hypotheses for the further studies.

\section{Discussion and conclusion}

Researchers performing experiments using novel genomic research methods often face the challenge of combining their experimental results with results derived from different heterogeneous sources, such as experiments conducted using different technologies, different model organisms or results retrieved from public databases. We have developed a web-based software program called CROPPER that automates this task.

Several compendium studies that combine data from different sources have been published, but it is common that the actual combination and integration of the data has been done using custom-made software programs and scripts that are useful only for the data used for the specific study [10-12]. This has resulted in the need of complete end-user programs that biologists can use to combine their datasets. Different resources have been developed to address this challenge [13-18], but are hindered by several limitations. These limitations include focusing on a single (or very limited amount) of species/technology, requiring a strict pre-defined format on datasets, not allowing customisation of the result file or including actual experimental data in the dataset. CROPPER differs from these resources by giving users a good flexibility on how to import and export data and broad coverage of all the major databases, technologies and species, making CROPPER useful for a very wide variety of users.

One of the main strengths of CROPPER is that it uses the Ensembl-database, therefore ensuring that all the major data sources and species are covered, and that the data is always up-to-date. What distinguishes CROPPER from the data mining tools provided by Ensembl $[19,20]$, is that CROPPER is specially designed for automated data integration, implementing the original metagene approach, therefore allowing users to combine numerous distinct datasets, bring the experimental data along, and not requiring other software or programming tools to facilitate the combining. This is in addition to its ease of use to help biologists combine their datasets and to gain increased power for their research, which could not be obtained by direct usage of Ensembl data mining tools. Moreover, users do not need to be familiar with Ensembl or their data mining tools to use CROPPER.

When performing compendium studies, the researcher should pay attention to the steps taken in data combining. For example it should be clear that when cross-linking gene datasets to protein datasets, accuracy is lost. It is also lost when combining datasets derived from different technologies. For example, when combining data from cDNA and oligonucleotide microarrays, the actual experimental measurements are very rarely directly comparable. It should be noted that CROPPER only combines the related data rows, but does not alter the experimental data in any way. Therefore it is likely that depending on the type of the study, different methods and tools are required to make the data comparable. In many cases, the Z-ratio method presented here will work, but other methods can also be used. Many statistical and computational methods and software are publicly or commercially available towards this end. When performing compendium studies, the combining of data elements is usually the first and most difficult task and using CROPPER helps researchers to overcome this major bottle-neck in the integration of genomic data.

\section{Availability and requirements Project name: CROPPER}

Project homepage: http://katiska.uku.fi/ jmpaanan/ cropper/

Operating system(s): Platform independent

Programming language: Perl

\section{Other requirements:}

License: Free for academic use

Any restrictions to use by non-academics: License needed

\section{Authors' contributions}

JP designed and developed the methodology and software and drafted the manuscript. MS performed the compendium study and helped to draft the manuscript. GW conceived the study, participated in its design and coordination and helped to draft the manuscript. All authors read and approved the final manuscript.

\section{Additional material}

\section{Additional File 1}

Combined data used for the example analysis. Combined data from the four different neurodegenerative studies, used for the example compendium study. Data presented with z-ratios (treatment vs. the absolute control) and the genes regulated in human and/or in other organisms are presented.

Click here for file

[http://www.biomedcentral.com/content/supplementary/14712105-7-418-S1.xls] 


\section{Additional File 2}

The biological themes and patterns detected in the combined data. First worksheet contains the enriched KEGG pathways, number of genes with association to a pathway, and the p-value for the statistical significance. Second and third worksheet contain the enriched GO terms detected in the combined data, clustered into 1,2 and 3 clusters based on the associated GO terms.

Click here for file

[http://www.biomedcentral.com/content/supplementary/14712105-7-418-S2.xls]

\section{Acknowledgements}

JP was financially supported by the A.I. Virtanen Institute Graduate School and Academy of Finland. MS was supported by grants from the University of Kuopio. GW was supported by the Academy of Finland and University of Kuopio. The authors thank Suvi Vartiainen, Jani Kekäläinen, Petri Pehkonen and Petri Törönen for discussions and helpful comments. The support and development staff of the Ensembl project are acknowledged for their assistance during the project.

\section{References}

I. Birney E, Andrews D, Caccamo M, Chen Y, Clarke L, Coates G, Cox T, Cunningham F, Curwen V, Cutts T, Down T, Durbin R, FernandezSuarez XM, Flicek P, Graf S, Hammond M, Herrero J, Howe K, lyer V, Jekosch K, Kahari A, Kasprzyk A, Keefe D, Kokocinski F, Kulesha E, London D, Longden I, Melsopp C, Meidl P, Overduin B, Parker A, Proctor G, Prlic A, Rae M, Rios D, Redmond S, Schuster M, Sealy I, Searle S, Severin J, Slater G, Smedley D, Smith J, Stabenau A, Stalker J, Trevanion S, Ureta-Vidal A, Vogel J, White S, Woodwark C, Hubbard T): Ensembl 2006. Nucleic Acids Res 2006, 34(Database issue): D556-61.

2. Stajich JE, Block D, Boulez K, Brenner SE, Chervitz SA, Dagdigian C, Fuellen G, Gilbert JG, Korf I, Lapp H, Lehvaslaiho H, Matsalla C, Mungall CJ, Osborne BI, Pocock MR, Schattner P, Senger M, Stein LD, Stupka E, Wilkinson MD, Birney E: The Bioperl toolkit: Perl modules for the life sciences. Genome Res 2002, 12(10):1611-1618.

3. Stabenau A, McVicker G, Melsopp C, Proctor G, Clamp M, Birney E: The Ensembl core software libraries. Genome Res 2004, I 4(5):929-933.

4. Grunblatt E, Mandel S, Jacob-Hirsch J, Zeligson S, Amariglo N, Rechavi G, Li J, Ravid R, Roggendorf W, Riederer P, Youdim MB: Gene expression profiling of parkinsonian substantia nigra pars compacta; alterations in ubiquitin-proteasome, heat shock protein, iron and oxidative stress regulated proteins, cell adhesion/cellular matrix and vesicle trafficking genes. J Neural Transm 2004, III ( I 2): 1543-I573.

5. Vartiainen S, Pehkonen P, Lakso M, Nass R, Wong G: Identification of gene expression changes in transgenic $C$. elegans overexpressing human alpha-synuclein. Neurobiol Dis 2006, 22(3):477-486.

6. Bassilana F, Mace N, Li Q, Stutzmann JM, Gross CE, Pradier L, Benavides J, Menager J, Bezard E: Unraveling substantia nigra sequential gene expression in a progressive MPTP-lesioned macaque model of Parkinson's disease. Neurobiol Dis 2005, 20(I):93-103.

7. Cheadle C, Cho-Chung YS, Becker KG, Vawter MP: Application of z-score transformation to Affymetrix data. Appl Bioinformatics 2003, 2(4):209-2I7.

8. Dennis GJ, Sherman BT, Hosack DA, Yang J, Gao W, Lane HC, Lempicki RA: DAVID: Database for Annotation, Visualization, and Integrated Discovery. Genome Biol 2003, 4(5):P3.

9. Pehkonen $P$, Wong $G$, Toronen $P$ : Theme discovery from gene lists for identification and viewing of multiple functional groups. BMC Bioinformatics 2005, 6:162.

10. Bergmann S, Ihmels J, Barkai N: Similarities and differences in genome-wide expression data of six organisms. PLoS Biol 2004 , 2(I):E9.
II. Kim SK, Lund J, Kiraly M, Duke K, Jiang M, Stuart JM, Eizinger A, Wylie BN, Davidson GS: A gene expression map for Caenorhabditis elegans. Science 2001, 293(5537):2087-2092.

12. McCarroll SA, Murphy CT, Zou S, Pletcher SD, Chin CS, Jan YN, Kenyon C, Bargmann Cl, Li H: Comparing genomic expression patterns across species identifies shared transcriptional profile in aging. Nat Genet 2004, 36(2):197-204.

13. Cheung KH, Hager J, Pan D, Srivastava R, Mane S, Li Y, Miller P, Williams KR: KARMA: a web server application for comparing and annotating heterogeneous microarray platforms. Nucleic Acids Res 2004, 32(Web Server issue):W44I-4.

14. Diehn M, Sherlock G, Binkley G, Jin H, Matese JC, Hernandez-Boussard T, Rees CA, Cherry JM, Botstein D, Brown PO, Alizadeh AA: SOURCE: a unified genomic resource of functional annotations, ontologies, and gene expression data. Nucleic Acids Res 2003, 3 I (I):219-223.

15. Kulkarni AV, Williams NS, Lian Y, Wren JD, Mittelman D, Pertsemlidis A, Garner HR: ARROGANT: an application to manipulate large gene collections. Bioinformatics 2002, I8(II):1410-1417.

16. Tsai J, Sultana R, Lee Y, Pertea G, Karamycheva S, Antonescu V, Cho J, Parvizi B, Cheung F, Quackenbush J: RESOURCERER: a database for annotating and linking microarray resources within and across species. Genome Biol 200I, 2(I I):SOFTWARE0002.

17. Wang P, Ding F, Chiang H, Thompson RC, Watson SJ, Meng F: ProbeMatchDB--a web database for finding equivalent probes across microarray platforms and species. Bioinformatics 2002, I 8(3):488-489.

18. Bussey KJ, Kane D, Sunshine M, Narasimhan S, Nishizuka S, Reinhold WC, Zeeberg B, Ajay W, Weinstein JN: MatchMiner: a tool for batch navigation among gene and gene product identifiers. Genome Biol 2003, 4(4):R27.

19. Kasprzyk A, Keefe D, Smedley D, London D, Spooner W, Melsopp C, Hammond M, Rocca-Serra P, Cox T, Birney E: EnsMart: a generic system for fast and flexible access to biological data. Genome Res 2004, I4(I): 160-169.

20. Durinck S, Moreau Y, Kasprzyk A, Davis S, De Moor B, Brazma A, Huber W: BioMart and Bioconductor: a powerful link between biological databases and microarray data analysis. Bioinformatics 2005, 21 (16):3439-3440.

Publish with Bio Med Central and every scientist can read your work free of charge

"BioMed Central will be the most significant development for disseminating the results of biomedical research in our lifetime. "

Sir Paul Nurse, Cancer Research UK

Your research papers will be:

- available free of charge to the entire biomedical community

- peer reviewed and published immediately upon acceptance

- cited in PubMed and archived on PubMed Central

- yours - you keep the copyright
BiolMedcentral 